doi: 10.18484/2305-0047.2017.3.115

\author{
E.V. BARANOV ${ }^{1}$, A.V. BURAVSKY ${ }^{1}$, Z.B. KVACHEVA ${ }^{2}$,
} A.V. BUTENKO ${ }^{2}$, D.S. TRETYAK ${ }^{3}$, N.K. YURKSHTOVICH ${ }^{4}$, L.V. CEDIK ${ }^{5}$, S.I. TRETYAK ${ }^{1}$, I.D. VOLOTOVSKY ${ }^{2}$

\title{
POTENTIAL OF USING CULTIVATED DERMAL FIBROBLASTS ON THE BIODEGRADABLE POLYMERIC MATRICES FOR TREATING SKIN DAMAGES IN THE EXPERIMENT
}

\author{
EE "Belarusian State Medical University" ', \\ SRE "Institute of Biophysics and Cell Engineering of NAS of Belarus" 2, \\ SE "The 432 ${ }^{\text {nd }}$ Chief Military Clinical Medical Center of the Armed Forces of the Republic of Belarus" 3 , \\ EE "Belarusian State University" 4, \\ SNE "Powder Metallurgy Institute" 5 , \\ Minsk \\ The Republic of Belarus
}

\begin{abstract}
Цель. Оценить возможность применения культивированных дермальных фибробластов на полимерных биодеградируемых матрицах для лечения повреждений кожного покрова в эксперименте.

Материал и методы. Исследование выполнено на 90 крысах линии Wistar массой тела 180-200 г, с чистыми ранами диаметром 2,5 см. Было сформировано 6 групп - по животных в каждой. Культуру дермальных фибробластов выделяли из кожи новорожденных крыс; для накопления необходимой биомассы клеток проводили субпассирование. В 1 группе (контроль) клеточные биопрепараты не применялись. В группах 2-6 для лечения экспериментальных ран были использованы биодеградируемые матрицы (фосфат декстрана либо полилактид) как без клеточного биопрепарата, так и с содержанием культивированных фибробластов в количестве от $250 \times 10^{3}$ до $700 \times 10^{3}$ клеток на один раневой дефект. Выводы о влиянии дермальных фибробластов на полимерных биодеградируемых матрицах на раневой процесс делали на основании сравнительного анализа результатов компьютерной планиметрии и морфологического исследования.

Результаты. На всех этапах $(7,14,21,28$ сутки) эксперимента минимальная скорость заживления была зарегистрированы в группе 1. Шестая группа, в которой в рану вносили полилактид, содержащий $700 \times 10^{3}$ клеток, характеризовалась максимальными - относительно остальных групп - значениями скорости заживления. В микропрепаратах 6 группы на 21 сутки эксперимента отмечена полная эпителизация раневого дефекта. Выявлено наличие сильной прямой корреляционной связи между количеством трансплантированных клеток и скоростью заживления раневых дефектов на 7 сутки $(\rho=0,923), 14$ сутки $(\rho=0,924)$, а также 21 сутки эксперимента $(\rho=0,914)$.

Заключение. В условиях эксперимента установлено, что локальное применение культивированных дермальных фибробластов на полимерных биодеградируемых матрицах (фосфат декстрана и полилактид) ведет к достоверному сокращению сроков эпителизации раневых дефектов.
\end{abstract}

Ключевые слова: фибробласты кожи крысы, фосфат декстрана, полилактид, биодеградируемые матрицы, лечение ран, эпителизация, эксперимент

Objectives. To evaluate the possibility of using of cultivated dermal fibroblasts on the biodegradable polymeric matrices for treating skin damages in the experiment.

Methods. The study was performed on 90 rats of Wistar line (180-200 g weight) with pure wounds (D-2,5cm). Six groups were formed, 15 animals per each group. The culture of dermal fibroblasts was isolated from the skin of newborn rats; to accumulate the required biomass of cells subpassage was carried out.

The cellular biological products were not applied in group 1 (control). Biodegradable matrices (dextran phosphate or polylactide) were used for treating wounds in the groups 2-6 as matrices without cellular biological product and matrices with cultured fibroblasts $\left(250 \times 10^{3}\right.$ to $700 \times 10^{3}$ cells per wound). Conclusion about the impact of biodegradable polymeric matrices with dermal fibroblasts on the wound healing was made on the basis of a comparative analysis of the results of digital planimetry and morphological studies.

Results. At all stages $(7,14,21,28$ days) minimal rate of healing was registered in the first group. The sixth group, where polylactide containing $700 \times 10^{3}$ cells was added in the wound, is characterized by the biggest values of the healing rate - with respect to other groups. Complete epithelization of the wound defects in the micropreparations of the sixth group was marked by the $21^{\text {st }}$ day of the experiment. The strong direct correlation between the number of transplanted cells and wound rate healing was detected on the 7 th day $(\rho=0,923)$, the $14^{\text {th }}$ day $(\rho=0,924)$, and the $21^{\text {st }}$ day of the experiment $(\rho=0,914)$. 
Conclusion. In the experiment it has been found out, that local application of the cultivated dermal fibroblasts on biodegradable polymer matrices (dextran phosphate and polylactide) results in a significant reduction of terms of the wound epithelization.

Keywords: rat skin fibroblasts, dextran phosphate, polylactide, biodegradable matrices, wound treatment, epithelization, experiment

Novosti Khirurgii. 2017 May-Jun; Vol 25 (3): 223-232

Potential of Using Cultivated Dermal Fibroblasts on the Biodegradable

Polymeric Matrices for Treating Skin Damages in the Experiment

E.V. Baranov, A.V. Buravsky, Z.B. Kvacheva, A.V. Butenko, D.S. Tretyak,

N.K. Yurkshtovich, L.V. Cedik, S.I. Tretyak, I.D. Volotovsky

\section{Introduction}

The actual issue of development of effective approaches to the treatment of patients with the long-term non-healing wounds, decubital defects, trophic ulcers of various etiologies, extensive skin burns still remains the big one. In the opinion of some authors the insufficiency of conventional treatment methods may often be caused by local pathological homeostasis, which is exerted by the human body's own potential regenerative cells to close the wound defect $[1,2,3]$. One of the alternative and promising components of complex treatment of this patients category appears to be a local application of cellular technologies to stimulate reparative regeneration $[4,5,6,7]$.

The cultivation and accumulation of the biomass of progenitor cells and differentiated skin cells outside the body and the performance of subsequent local cell transplantation, aimed at restoring the structural and functional integrity of the damaged skin, is now becoming more actual in biotechnology and medicine and has been already widely used $[8,9,10,11]$. However, there are a number of controversial aspects and unsolved issues, one of which is the choice of the delivery ways of the cellular biomaterial to a pathological focus. Currently, there are two main ways of local application of cellular products for medical purposes:

- cultivation, differentiation, selection and local delivery of cellular material in the form of suspension into the site of injury;

- creation of two or three-dimensional structures consisting of composite biological materials or biodegradable substrate containing various cellular products that are implanted as a part of complex transplants into (or on) a damaged organ or tissue.

Many researchers have noted that when monolayer cultured in vitro is transferred to the suspension, a certain reduction of the functional cellular activity may occur. In some cases, the damage and death of the part of the cellular biomaterial is related with proteolytic enzymes treatment, which is necessary to separate the monolayer of cells from the surface of the culture container [12, 13]. However, the cultivation of cells and their immobilization on biocompatible polymer matrices with the subsequent application of the engineering tissues utilizing biodegradable polymer matrices on a wound enable to neutralize the negative aspects of the suspension techniques of transplantation $[3,4,6,14]$. This study provides a literature review of various polymeric biomaterials, both natural and synthetic, considered as carriers.

The commercial wound coatings (based on chitosan, collagen, artificial polymers, etc.) possessing by declared positive properties are presented in a large number in the market of medical products. However, it has not been yet able to create a universal matrix that would have a definite cumulative list of necessary properties, namely: a complete biocompatibility with no pyrogenic, toxic and irritating effects on surrounding tissues; exudates absorption capacity; the ability to create the optimal microenvironment for wound regeneration; the absolute barrier for microorganisms; providing adequate moist and gas exchange; elasticity and the ability to model the surfaces with complex relief; a controlled biodegradation [10, 14].

No less important criteria in choosing a polymer matrix for the formation of engineering tissues are: the absence of toxic effects to cultured cells; the ability to provide favorable conditions for attachment, reproduction, directed differentiation and growth of cellular biomaterial both on the surface and in the internal structure of the carrier, as well as the synthesis of extracellular matrix proteins $[5,15]$.

Therefore, the search, development and scientific substantiation of the effectiveness of new resorbable matrices for the cultivation and immobilization of cellular biomaterial are considered to be a promising and necessary direction for experimental and clinical research.

Objectives. To evaluate the possibility of using cultivated dermal fibroblasts on the biodegradable polymeric matrices for treating skin damages in the experiment.

\section{Methods}

Preparation of primary cultures and subcultures of skin fibroblasts. Wistar newborn rats were used in the experiments. The skin was taken from the back 
of a rat in sterile conditions. The primary culture of rat dermal fibroblasts was prepared by the explant method [5] according author's modification. Cell cultivation was carried out in DMEM (Sigma) nutrient medium with $10 \%$ of the cow fetus serum (HyClon) in a $\mathrm{CO}_{2}$ incubator at $+37^{\circ} \mathrm{C}, 5 \% \mathrm{CO}_{2}$. The medium was changed every 3-4 days. After cells migration from the explants and the formation of the primary culture monolayer, subpassing was carried out within 3-6 passages to accumulate the necessary biomass of cells (25-30 million) and further local transplantation to experimental animals with the wound defects.

Preparation of cell suspension for transplantation. The cell cultures at the late stage of logarithmic growth after the formation of a monolayer (4-5 days) were used in the experiments. To transfer the cells from the monolayer to suspension the cells were treated with $0,25 \%$ trypsin and $0,02 \%$ versen (1:2 ratio). For transplantation, a suspension of dermal fibroblasts was used at the concentration of 250$700 \times 10^{3}$ cells $/ \mathrm{ml}$.

Resorbable film from polylactide and its preparation for cell cultivation. The transparent films $0,1-$ $0,2 \mathrm{~mm}$ thick (developed by the employees of the group "Biomaterials and Biomedical Products" of SEE "Institute of Powder Metallurgy", Minsk) were used in the study. Sterilization of polylactide films was carried out by ultraviolet radiation in a laminar box within 18-24 hours. To ensure the sterilization process has performed adequately it was evaluated by the absence of growth of bacteria, mycoplasmas, fungi after flushing from the film into nutrient microbiological media (thioglycolic medium, Saburo medium, etc.). The polylactide film was placed on the bottom of a culture flask containing the suspension of dermal fibroblasts at the concentration of $700 \times 10^{3}$ cells $/ \mathrm{ml}$.

Preparation of dextran phosphate gel for the immobilization of cells. The drug was developed at the Research Institute of Physical and Chemical Problems of the Belarusian State University, Minsk. Preliminary prepared preparations in the flasks $(90$ mg per each) were subjected to gamma irradiation sterilization. Before transplantation, $10 \mathrm{ml}$ of a nutrient medium containing a cell suspension was added to each flask, shaken within 5 minutes, and then it was left in a thermostat at $37^{\circ} \mathrm{C}$ within 30 minutes.

Technique of experimental wound modeling. Methods of transplantation and evaluation of therapeutic efficacy. The study was performed on 90 male rats (8-10 week old) Wistar lines weighing 180-200 gr.; they were housed in individual separate cages under standard vivarium conditions (a temperature of $18-20^{\circ} \mathrm{C}$ and $55 \%$ relative humidity) with free food and water. All studies were conducted accord- ing to the ethical standards given in the Declaration of Helsinki taking into account the welfare of animals used for research purposes.

In accordance with the principles of aseptic and antiseptic technique after intraperitoneal anesthetics with $0,5-0,7 \mathrm{ml}$ sodium thiopental $(1 \%)$ was used (rating 40-60 mg/kg), exposure within 15-20 minutes and fixation on the animal's back, skin area $(3 \times 3 \mathrm{~cm})$ was shaved. On the depilated rat's skin a contour of the future wound was marked with a brilliant green solution: a circle $(\mathrm{D}-2,5 \mathrm{~cm})$. The skin was treated twice with the antiseptic "Iodonat". A round-shaped wound with a diameter of $2,5 \mathrm{~cm}$ was inflicted, excising the skin, subcutaneous tissue and fascia to the muscles. Then, local treatment was performed: prepared matrices without and with cellular biomaterial as a part of a complex transplant were transferred to a skin defect. In all groups of experimental animals the wound surfaces were covered with a sterile transparent coating based on polyurethane, which reduced the probability of contamination of the wound outside, provided adequate moist and gas exchange, and monitoring wound healing.

To conduct systemic antibiotic therapy with ceftriaxone $(5 \mathrm{mg} / \mathrm{kg})$ the rats were injected intramuscularly $(25 \mathrm{mg} / \mathrm{kg})$ during the first 10 days of the experiment.

Six experimental groups were formed.

In the $1^{\text {st }}$ group (control, $n=15$ ) cellular biopreparations were not used.

In the $2^{\text {nd }}$ group $(n=15)$ the wound defect was filled with dextran phosphate (PD) gel without a cell biopreparation.

In the $3^{\text {rd }}$ group $(n=15)$ the wound defect was filled with $0,8 \mathrm{ml}$ of PD gel containing cultured rat skin fibroblasts (RSF) in the amount of $250 \times 10^{3}$ cells.

In the $4^{\text {th }}$ group $(n=15)$ the wound defect was filled with $1 \mathrm{ml}$ of PD gel containing $500 \times 10^{3}$ of RSF.

In the $5^{\text {th }}$ group $(n=15)$ the wound was packed with a polylactide film (PF) without a cellular preparation.

In the $6^{\text {th }}$ group $(n=15)$ the wound was packed with PF with fibroblasts fixed on it $\left(700 \times 10^{3}\right.$ of RSF).

Methods for recording the state of wounds after transplantation.

The day of simulation of the experimental wound was considered as the zero day of the experiment in all cases, the wound area was considered to be equal to $100 \%$. Planimetric studies as well as a visual assessment of the condition were performed daily. Gradual removal of rats from the experiment (with subsequent histomorphological study of preparations) was performed on the $7^{\text {th }}, 14^{\text {th }}, 21^{\text {st }}$ and $28^{\text {th }}$ days. 
Computer - assisted planimetric measurements were used for determination of wound healing dynamics.

Calculation of wound healing velocity $\left(v_{\text {healing }}\right.$, $\% /$ days) was done according to the formula:

$$
\frac{\left(\mathrm{S}_{0}-\mathrm{S}_{\mathrm{n}}\right) \times 100 \%,}{\mathrm{~S}_{0} \times \mathrm{n}}
$$

где $\mathrm{S}_{0}$ - initial wound area, $\mathrm{Sn}$ - wound area on the certain day, $\mathrm{n}-$ the serial number of the day of the experiment.

Calculation of the reduction of wound area $(\Delta \mathrm{S}, \%)$ for a definite period of observation was carried out according to the formula:

$$
\frac{\left(\mathrm{S}_{0}-\mathrm{S}_{\mathrm{n}}\right) \times 100 \%}{\mathrm{~S}_{0}}
$$

where $\mathrm{S}_{0}$ - initial wound are, $\mathrm{Sn}$ - wound area on the definite day.

Conclusions on the effect of transplantation of dermal fibroblasts and cellular biopreparations on the wound process were made on the basis of a comparative evaluation of the results of the experimental groups. The data of visual observation, computer planimetry (indices of the changes in the areas of wound defects $\Delta \mathrm{S}$, as well as the healing $v_{\text {healing }}$ in the course of the experiment) were analyzed.

Morphological methods of research. The explanted tissue pieces from the site of wound skin defects were fixed in $10 \%$ neutral formalin for 48 hours. Then they were washed in running water for 24 hours, dehydrated in alcohols of elevated concentration (70, 80, 96, absolute alcohol). Further, the material was conducted through alcohol-chloroform, chloroform, chloroformparaffin and poured into paraffin. From the paraffin blocks, sections of 4-5 microns thick were made, which were stained with hematoxylin and eosin. The study of microscopic preparations and the preparation of micrographs were carried out using an Axio Imager (ZEISS) microscope in different fields of view.

Statistical processing of the staby results of the study was performed using nonparametric tests. Data are presented in the form of "median and quartile" - Me (Q25;Q75). Mann-Whitney U test and Kruskal-Wallis test was used for comparisons of differences of independent groups. The Friedman test was used for paired samples and Wilcoxon test matched pairs, with a Bonferroni adjustment on the results getting from the Wilcoxon tests. The Spearman's Rank-order Correlation was used to test the association between two ranked variables.

Differences were considered statistically significant in the probability of an error-free prognosis was not less than $95 \%(\mathrm{p}<0,05)$.

\section{Results}

Characteristics of skin fibroblast cultures of newborn rats. Monolayer cultures were represented by spindle-shaped fibroblast-like cells. At a seed dose $(150-200) \times 10^{3}$ of cells / $\mathrm{ml}$, a monolayer of dermal fibroblasts was formed within 5-7 days. The proliferation index in 1-6 sub-passages was at the same level and made up 3,8-4,0. The mitotic activity of cells in the logarithmic growth phase varied from 30 to $34 \mathrm{ppm}$. The viability of cells in suspension (at least $98 \%$ of living cells) was assessed prior to transplantation.

Assessment of the biocompatibility of cells cultured on a polylactide film and immobilized in dextran phosphate gel.

The biocompatibility of the polylactide film with the cells was evaluated by the following criteria: the ability of the cells for adhesion; proliferation on the film; for proliferation and formation of the monolayer of cells compared to cells grown under usual conditions. During the incubation of PF in the growth medium for 7 days, altering $\mathrm{pH}$ value within the range permissible to growth $(6,8-7,1)$ was noted. When cultivating fibroblasts on a polylactide film, no differences were observed in the biocompatibility parameters compared to the control cultures. Thus, in seeding, adhesion and cell proliferation on the film was registered after 18-24 hours; and the terms of formation of the monolayer of cells and the morphology of the cells was the same as in the control cultures growing on plastic. The proliferation index of cells growing on the polylactide matrix was $2,9 \pm 0,3$. This index did not differ significantly from the control level: the cell proliferation index on the plastic was within $3,1 \pm 0,2$. In all cases, the same seed dose of cells was used $(\mathrm{p}>0.05)$.

When the dextran phosphate gel was applied to the DMEM (Sigma) nutrient medium with $10 \%$ of cow fetus serum (HyClon), the $\mathrm{pH}$ also remained within the range permissible for cell growth in culture $(6,8-7,1)$ for 7 days of the observation. When fibroblasts with the pieces of gel were grown for 7 days, their proliferative activity, morphology, monolayer formation time and biomass accumulation during cultivation did not differ from the control ones cultivated without PD. The increase of the number of cells, both in the experimental and control groups, was the same and did not differ significantly. The cell proliferation index in cultures was 2,8 and 2,7 , respectively $(p>0,05$ ). When observing the fibroblasts immobilized in the PD gel, no negative effect of the drug was detected within 3-6 days. 
Thus, the assessment of the biocompatibility of the selected matrix carriers showed no cytotoxic effect of dextran phosphate hydrogel and polylactide film on the cultivated dermal fibroblasts, which became the basis for their further use for immobilizing cell cultures and carrying out cellular transplantation in the treatment of experimental wounds.

Dynamics of regenerative processes in experimental wounds in animals under various conditions and methods of cell transplantation.

Analysis of the initial areas of wound defects $\left(\mathrm{S}, \mathrm{cm}^{2}\right)$ permitted to conclude that there were no significant differences between the groups (Kruskal-Wallis test: $\mathrm{H}=2,50, \mathrm{p}=0,960$ ). This was important for the subsequent objective evaluation of the study results, statistical processing and inter-group comparison of the obtained data about the dynamics of the areas of experimental wounds $(\Delta \mathrm{S}, \%)$, as well as wound healing velocity $\left(v_{\text {healing }}\right.$ $\%$, per day).

In monitoring the animals of the control and experimental groups during the whole period of the experiment ( 28 days) and measuring the wound areas, significant inter- and intra group differences in the dynamics of wound defects healing were found on the basis of a comparative analysis of $\Delta \mathrm{S}$ values (Table 1).

The analysis of the obtained data showed that the values of $\Delta \mathrm{S}$ of the first group (control) were significantly less than the corresponding parameters of any of the experimental groups at all stages of the experiment ( $p<0,05$ in all cases).

In evaluating the $\Delta \mathrm{S}$ indices, no significant differences were found between the groups where the selected biomatrices were used (the second group - PD gel and the fifth group $-\mathrm{PF}$ ): the $7^{\text {th }}$ day $-\mathrm{U}=30,5$ and $\mathrm{p}=1,7 ;$ the $14^{\text {th }}$ day $-\mathrm{U}=28,5$ and $\mathrm{p}=1,2 ;$ the $21^{\text {st }}$ day $-\mathrm{U}=39,0$ and $\mathrm{p}=6,2$; the 28 day $-\mathrm{U}=26,0$ and $\mathrm{p}=13,2$.

In all control points of the experiment (the $7^{\text {th }}$, $14^{\text {th }}, 21^{\text {st }}$ and $28^{\text {th }}$ days), the healing parameters of wound defects (dynamics of the $\Delta \mathrm{S}$ area and the estimated healing speed $v_{\text {healing }}$ ) after the addition of dextran phosphate and polylactide (the second and fifth experimental groups) were significantly higher $(p<0,05$ in all cases) than in the control group. The values of $\Delta \mathrm{S}$ in the animals of the sixth group (PPF+ $700 \times 10^{3}$ cells in the monolayer) were significantly higher than the $\Delta \mathrm{S}$ values of the remaining groups in all control points of the experiment (the exception - absence of differences with the parameters of the fourth group on the $21^{\text {st }}$ day of the experiment $-\mathrm{U}=32,5$ and $\mathrm{p}=2,3$ ).

Comparative analysis of healing velocity of wound defects allowed revealing statistically significant intergroup differences in $v_{\text {healing }}$ values in the experiment (Table 2).

The minimum values of $v$ healing at the control points were recorded in the first group (compared with the results of the remained groups $p<0,05$ in all cases). Significant differences between the second and fifth groups were noted only on $21^{\text {st }}$ day $(\mathrm{U}=28,5, \mathrm{p}=0,03)$. The results of the third group were higher than the $v_{\text {healing }}$ values of the second and fifth groups $((p<0,05$ in all cases). The values of the sixth group (a polylactide film with fixated fibroblasts $\left(700 \times 10^{3} \mathrm{RSF}\right.$ in the monolayer) were significantly higher than the healing values of the remaining groups in all cases (exception - an absence of differences of the values of the fourth group on the $21^{\text {st }}$ day of the experiment $-\mathrm{U}=32,5$ and $\mathrm{p}=0,07)$.

Dynamics of $\Delta \mathbf{S}$ indices in the experimental groups

Table 1

\begin{tabular}{|c|c|c|c|c|}
\hline \multirow[t]{2}{*}{ Group } & \multicolumn{4}{|c|}{$\begin{array}{c}\text { Reduction of the wound defects areas } \Delta \mathrm{S}, \%-\mathrm{Me}\left(\mathrm{Q}_{25} ; \mathrm{Q}_{75}\right) \\
\text { Days of experiment }\end{array}$} \\
\hline & 7 & 14 & 21 & 28 \\
\hline First (Control) $\quad(n=11)$ & $26,9(25,4 ; 28,2)$ & $54,3(53,6 ; 56,2)$ & $66,7(64,3 ; 70,8)$ & $81,7(80,3 ; 83,6)$ \\
\hline Second (PD gel) $(n=11)$ & $\begin{array}{c}29,2(29,0 ; 30,4) \\
p_{1}=0,00\end{array}$ & $\begin{array}{c}58,3(57,4 ; 60,3) \\
\mathrm{p}_{1}=0,00\end{array}$ & $\begin{array}{c}73,6(72,2 ; 75,0) \\
\mathrm{p}_{1}=0,00\end{array}$ & $\begin{array}{c}85,3(84,1 ; 87,3) \\
\mathrm{p}_{1}=0,00\end{array}$ \\
\hline $\begin{array}{l}\text { Third (PD gel }+250 \text { thousands } \\
\text { cells) }(n=11)\end{array}$ & $\begin{array}{c}35,8(33,3 ; 36,5) \\
\mathrm{p}_{1-2}=0,00\end{array}$ & $\begin{array}{l}69,4(68,5 ; 73,0) \\
\mathrm{p}_{1-2}=0,00\end{array}$ & $\begin{array}{l}85,1(84,3 ; 88,6) \\
\mathrm{p}_{1-2}=0,00\end{array}$ & $\begin{array}{c}94,6(91,4 ; 95,8) \\
\mathrm{p}_{1-2}=0,00\end{array}$ \\
\hline $\begin{array}{l}\text { Fourth }(P D \text { gel }+500 \\
\text { thousands cells) }(n=11)\end{array}$ & $\begin{array}{c}42,3(41,1 ; 42,9) \\
p_{1-3}=0,00\end{array}$ & $\begin{array}{c}85,5(84,3 ; 86,5) \\
p_{1-3}=0,00\end{array}$ & $\begin{array}{c}97,3(94,5 ; 100,0) \\
p_{1-3}=0,00\end{array}$ & $\begin{array}{c}100,0(98,6 ; 100,0) \\
p_{1-3}=0,00\end{array}$ \\
\hline Fifth $(P F) \quad(n=11)$ & $\begin{array}{c}30,6(30,0 ; 31,9) \\
\mathrm{p}_{1}=0,00 ; \mathrm{p}_{3-4}=0,00\end{array}$ & $\begin{array}{l}57,1(56,9 ; 59,2) \\
\mathrm{p}_{1}=0,00 ; \mathrm{p}_{3-4}=0,00\end{array}$ & $\begin{array}{c}74,6(73,9 ; 76,8) \\
\mathrm{p}_{1}=0,01 ; \mathrm{p}_{3-4}=0,00\end{array}$ & $\begin{array}{l}86,1(85,5 ; 87,3) \\
\mathrm{p}_{1}=0,00 ; \mathrm{p}_{3-4}=0,00\end{array}$ \\
\hline $\begin{array}{l}\text { Sixth }(P F+700 \text { thousands cells } \\
\text { in the monolayer })(n=11)\end{array}$ & $\begin{array}{c}47,1(45,7 ; 47,9) \\
\mathrm{p}_{1-5}=0,00\end{array}$ & $\begin{array}{c}89,7(87,1 ; 90,4) \\
\mathrm{p}_{1-5}=0,00\end{array}$ & $\begin{array}{l}100,0(97,1 ; 100,0) \\
\mathrm{p}_{1-3}=0,00 ; \mathrm{p}_{5}=0,00\end{array}$ & - \\
\hline Kruskel-Wallis test & $\begin{array}{l}\mathrm{H}=60,42 \\
\mathrm{p}=0,000\end{array}$ & $\begin{array}{l}H=60,14 \\
p=0,000\end{array}$ & $\begin{array}{l}\mathrm{H}=59,19 \\
\mathrm{p}=0,000\end{array}$ & $\begin{array}{l}\mathrm{H}=59,83 \\
\mathrm{p}=0,000\end{array}$ \\
\hline
\end{tabular}

Note. Mann-Whitney U-test amended by Bonferroni: p1 - reliability of differences with the group 1; p2 - -reliability of differences with group 2; 3 - reliability of differences with group 3; 4 - reliability of differences with group 4; p5 - reliability of differences with group 5. 
Dynamics $v_{\text {healing }}$ in experimental groups

Table 2

\begin{tabular}{|c|c|c|c|c|c|}
\hline \multirow[t]{3}{*}{ Group } & \multicolumn{4}{|c|}{$\begin{array}{l}\text { Speed of reduction of wound defects areas } v_{\text {healing, }} \\
\% / \text { days }-\operatorname{Me}\left(Q_{25} ; Q_{75}\right)\end{array}$} & \multirow[t]{3}{*}{ Friedman test } \\
\hline & \multicolumn{4}{|c|}{ Days of experiment } & \\
\hline & 7 & 14 & 21 & 28 & \\
\hline $\begin{array}{l}\text { First (control) } \\
(\mathrm{n}=11)\end{array}$ & $3,8(3,6 ; 4,0)$ & $3,9(3,8 ; 4,0)$ & $\begin{aligned} 3,2(3,1 ; 3,4) \\
* / * * \mathrm{p}=0,03\end{aligned}$ & $\begin{array}{c}2,9(2,9 ; 3,0) \\
* * * \mathrm{p}=0,03 ; * * * \mathrm{p}=0,04\end{array}$ & $\begin{array}{l}\text { ANOVA Chi Sqr. }=28,9 \\
\text { p }=0,000\end{array}$ \\
\hline $\begin{array}{l}\text { Second } \\
(\mathrm{n}=11)\end{array}$ & $4,2(4,1 ; 4,3)$ & $4,2(4,1 ; 4,3)$ & $\begin{array}{l}3,5(3,4 ; 3,6) \\
* / * * p=0,03\end{array}$ & 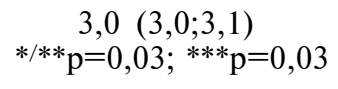 & $\begin{array}{l}\text { ANOVA Chi Sqr. }=30,3 \\
\text { p }=0,000\end{array}$ \\
\hline $\begin{array}{l}\text { Third } \\
(\mathrm{n}=11)\end{array}$ & $5,1(4,8 ; 5,2)$ & $5,0(4,9 ; 5,2)$ & $4,1(4,0 ; 4,2)$ & $3,4(3,3 ; 3,4)$ & $\begin{array}{l}\text { ANOVA Chi Sqr. }=30,3 \\
\text { p }=0,000\end{array}$ \\
\hline $\begin{array}{l}\text { Fourth } \\
(\mathrm{n}=11)\end{array}$ & $6,0(5,9 ; 6,1)$ & $6,1(6,0 ; 6,2)$ & $\begin{array}{r}4,6(4,5 ; 4,8) \\
* / * * \mathrm{p}=0,03\end{array}$ & $\begin{array}{c}3,6(3,5 ; 3,6) \\
* * * \mathrm{p}=0,03 ; * * * \mathrm{p}=0,03\end{array}$ & $\begin{array}{l}\text { ANOVA Chi Sqr. }=30,5 \\
\mathrm{p}=0,000\end{array}$ \\
\hline $\begin{array}{l}\text { Fifth } \\
(\mathrm{n}=11)\end{array}$ & $4,4(4,3 ; 4,6)$ & $4,1(4,1 ; 4,2)$ & $\begin{array}{r}3,6(3,5 ; 3,7) \\
* * * * \mathrm{p}=0,03\end{array}$ & $\begin{array}{c}3,1(3,1 ; 3,1) \\
* * * \mathrm{p}=0,03 ; * * \mathrm{p}=0,03\end{array}$ & $\begin{array}{l}\text { ANOVA Chi Sqr. }=32,5 \\
\text { p }=0,000\end{array}$ \\
\hline $\begin{array}{l}\text { Sixth } \\
(\mathrm{n}=11)\end{array}$ & $6,7(6,5 ; 6,8)$ & $\begin{array}{c}6,4(6,2 ; 6,5) \\
* p=0,05\end{array}$ & $\begin{array}{r}4,8(4,6 ; 4,8) \\
* / * * \mathrm{p}=0,03\end{array}$ & - & $\begin{array}{l}\text { ANOVA Chi Sqr. }=21,5 \\
\text { p }=0,000\end{array}$ \\
\hline
\end{tabular}

Note. Reliability of differences according to the Wilcoxon matched pairs test amended by Bonferroni at the intergroup comparison with the results at: $*-7, * *-14, * * *-21$ days.

Analysis of experimental outcomes according to the Spearman Rank Order Correlations revealed a statistically significant $(\mathrm{p}<0,05$ in all cases) presence of a strong direct correlation between the number of transplanted cells and the healing rate of wound defects on the $7^{\text {th }}$ day $(\rho=0,923)$, on the $14^{\text {th }}$ day $(\rho=0,924)$, and also on the $21^{\text {st }}$ day of the experiment $(\rho=0,914)$. Comparative analysis was carried out in the groups of experimental animals, where a biomatrix material were combined together with cellular material (groups 3, 4 and 6) containing different number of cultured fibroblasts $\left(250 \times 10^{3}\right.$, $500 \times 10^{3}, 700 \times 10^{3}$ cells).

The histomorphologic picture of wound defects in animals on the $21^{\text {st }}$ day of the experiment was characterized by necrosis of the surface areas with abundant infiltration by neutrophils and fibrin in the first group (control). The underlying fatty tissue appears to become progressively infiltrating and in some cases it may penetrate underlying muscle (Fig. 2).

On the $21^{\text {st }}$ day of the experiment (FD gel + $250 \times 10^{3}$ cells) the layer of fibrin with neutrophilic leukocytes was determined on the surface of the wound defect in the micropreparations in animals of the third group. The wound healing was represented by a granulation tissue - new connective tissue and microscopic blood vessels that form on the surfaces of a wound during the healing process so as fibroblasts, lymphocytes and neutrophils.

Intensive formation of thick collagen fibers was registered (Fig. 3).

In the fourth group ( $\mathrm{PD}$ gel $+500 \times 10^{3}$ cells), the almost completed epithelization of the wound defect had been determined in separate micropreparations by $21^{\text {st }}$ day of the experiment. In some places the remains of scab identified on the surface.

A small number of lymphocytes under the multilayered flat epithelium, as well as the presence of a maturing connective tissue with horizontally located fibroblasts and fibrocytes were seen (Fig. 4).

In micropreparations of the sixth group (PF + $700 \times 10^{3}$ cells) the completed epithelization of the wound defect was registered on the $21^{\text {st }}$ day of the experiment, (Fig. 5).

As a result of the performed studies (the second and fifth experimental groups, where only biodegradable matrices were used), no signs of allergenicity and reactogenicity of dextran phosphate gel and polylactide film were found (absence of fibrinoid necrosis and of a large number of multinucleated giant cells of foreign body resorption). These matrices in the animal body underwent complete biodegradation in the interval between $14^{\text {th }}$ and $21^{\text {st }}$ days after implantation.

Thus, the use of complex grafts consisting of both PF and PD and cultured dermal fibroblasts showed significant promotion of wound healing in experimental groups compared with the control group.

\section{Discussion}

The combination of innovative methods of treatment based on the local application of cellular technologies and bioengineering cellular and tissue structures indicates the emergence and formation of a new perspective direction of modern medicine regenerative and reconstructive-reconstructive surgery $[1,4,7]$. The thematic publications present the results of experimental studies that testify to the effectiveness of various cellular materials in carrier 

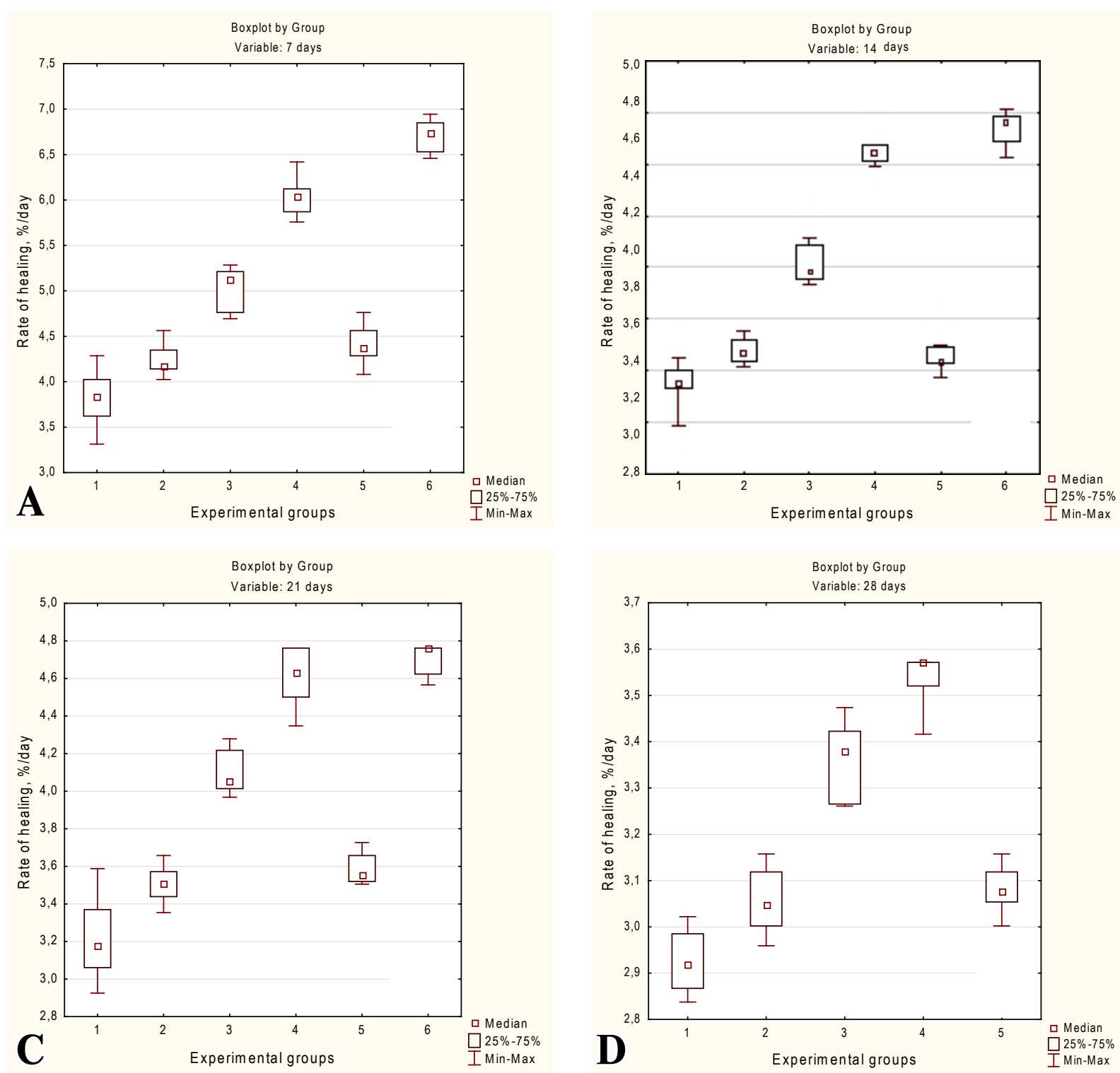

Fig. 1. Intergroup differences in healing velocity of wound defects. A - 7 day; B - 14 day; C -21 day; D - 28 day

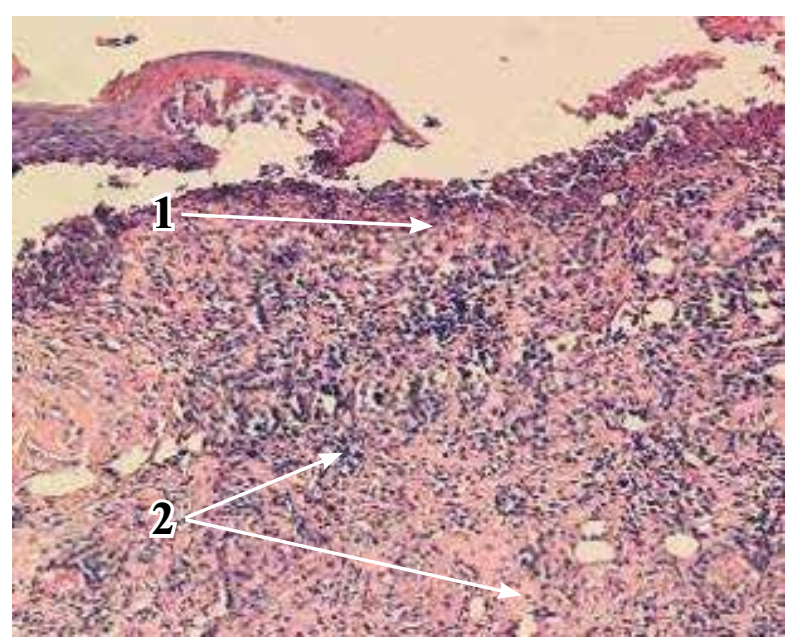

Fig. 2. The wound edge of the first group animal on the $21^{\text {st }}$ day of the experiment. 1 - necrosis of surface areas; 2 - neutrophil infiltration. Staining with hematoxylin and eosin. Magnification $\times 100$.

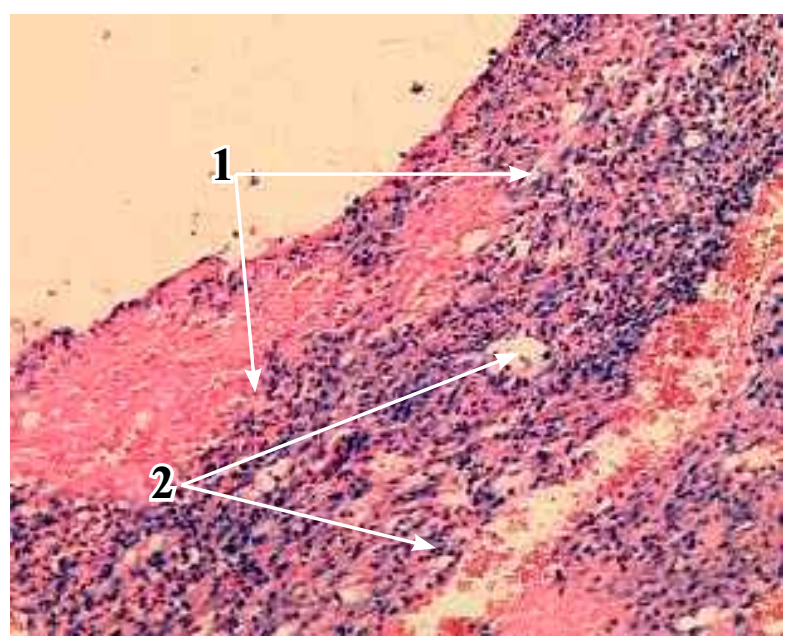

Fig. 3. The wound of the $3^{\text {rd }}$ group animal on the $21^{\text {st }}$ day of the experiment. 1 - fibrin with neutrophils; $2-$ maturing granulation tissue. Staining with hematoxylin and eosin. Magnification $\times \mathbf{1 0 0}$. 


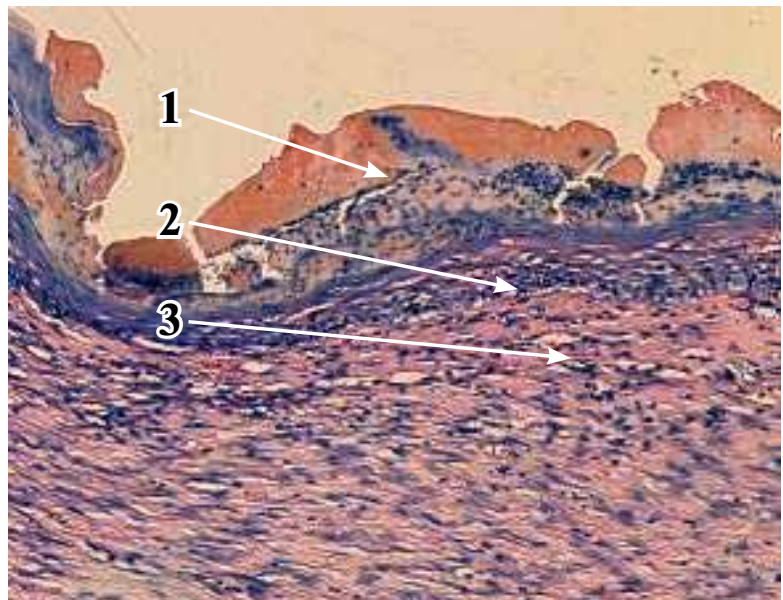

Fig. 4. The wound of the $4^{\text {th }}$ group animal on the $21^{\text {st }}$ day of the experiment. 1 - remains of the scab; 2 - multilayered flat epithelium; 3 - maturing connective tissue. Staining with hematoxylin and eosin. Magnification $\times 100$.

matrices to repair the damaged sites of various organs and tissues, including the heart, skin, bone, cartilage, etc. $[11,12,13,14]$. However, wide clinical introduction of treatment methods associated with the local application of cellular technologies is thought to be a scientific and practical perspective, whereas the solution of the fundamental problems of regenerative medicine, as a multidisciplinary trend, is still at the initial search level [2, 7, 12].

A lot of methods of isolation and cultivation of stem and differentiated skin cells have been developed. It appears that not all of them provide the express obtaining of the necessary biomass of cells and the creation of optimal conditions for their application in medical practice $[3,5]$. It is known that for a more complete realization of the structural and functional potential, the transplanted cells should retain viability and high proliferative activity in the tissue and in vitro. At present one solution this problem is thought to be used of the cellular material on carrier matrices; the various materials (from metals to polymers) have been proposed to produce them $[10,12,15]$. The latter, in their turn, are divided into two classes: natural and synthetic. Natural polymers (collagen, starch, chitin, chitosan, cellulose) have sufficiently low toxicity, good biocompatibility, possess by the ability to biodegrade. However, the presence of a number of such disadvantages as low mechanical resistance and the possibility of developing immune responses, as well as the variability of the physicochemical properties, makes these substrates limited for use in the preparation of matrices.

Unlike the natural carriers, synthetic polymers have more definite and stable properties (composition, charge, structure, mechanical properties, controlled biodegradability, etc.), which can be controlled and changed during manufacturing and

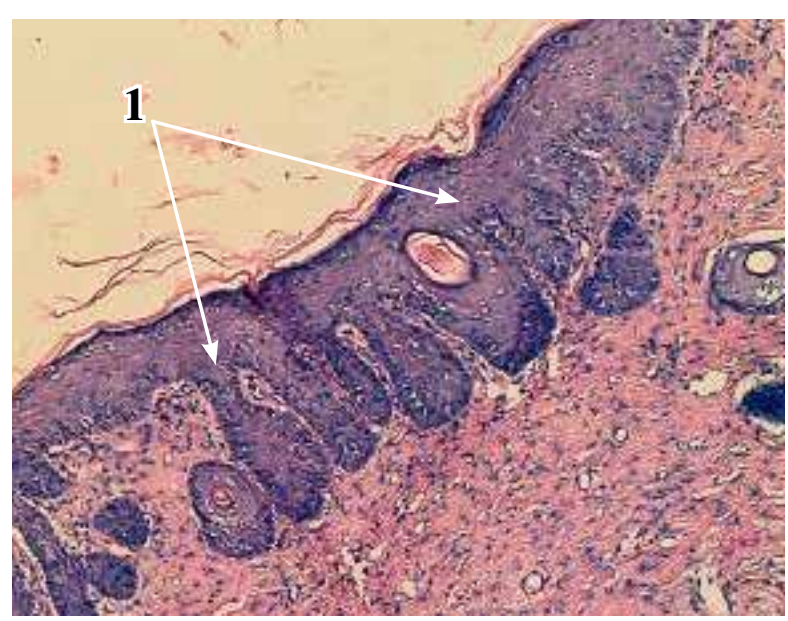

Fig. 5. The wound of the ${ }^{6 \text { th }}$ group animal on the $21^{\text {st }}$ day of the experiment. 1 - multilayered flat epithelium. Staining with hematoxylin and eosin. Magnification $\times 100$.

also standardized. Therefore, from the potential use point of view, synthetic polymeric materials are considered to be more convenient and promising for application in the form of substrates for cell growth [7, 12, 14].

\section{Conclusions}

1. The approved synthetic polymers (polylactide film and dextran phosphate gel) are characterized by the absence of cytotoxic effect, medium $\mathrm{pH}$ changes, some affection on the adhesive properties and proliferative activity of the dermal fibroblasts, as well as the term of formation of monolayer and morphology in comparison with the control cultures.

2. Experimental evaluation of using matrices without cell biomaterial has shown no signs or symptoms of allergenicity and reactogenicity of the dextran phosphate gel and polylactide film (biocompatible) to the surrounding tissues of the experimental skin wound after transplantation, the ability to accelerate the regeneration processes and good biodegradability in terms not exceeding the wound defect healing.

3. In studying the effectiveness of cellular compositions consisting of fibroblasts and matrices based on a polylactide film or dextran phosphate gel, a reliable reduction of time of wound defects epithelization has been established in compared with the normal wound healing in experimental animals.

4. Analysis of outcomes of experimental studies in vivo has demonstrated that the healing processes in experimental wound defects depends both on the conditions of transplantation (complex grafts) and on the amount of cellular biomaterial carriers.

5. Biopreparations, consisting of skin fibroblasts and resorbable polymers of polylactide and dextran phosphate, can be used in studies on the clinical 
application of local cell transplantation in the complex treatment of patients with chronic wounds of various etiologies, including trophic ulcers resistant to traditional methods of treatment.

\section{There is no conflict of interest}

\section{The work was performed in accordance with the Research Plan of EE "Belarusian State Medical University".}

\section{ЛИТЕРАТУРА}

1. Учкин ИГ, Багдасарян АГ. Современные подходы к лечению венозных трофических язв. РМЖ. Хирургия. 2005;21(15):810-14.

2. Абаев ЮК. Расстройство заживления ран и методы их коррекции. Вестн хирургии им ИИ Грекова. 2005;164(1):111-13.

3. Ehrlich HP. Understanding experimental biology of skin equivalent: from laboratory to clinical use in patients with burns and chronic wounds. Am J Surg. 2004 May; 187(5A):29S-33S.

4. Бабаева АГ. Регенерация - факты и перспективы. Москва, РФ: РАМН; 2009. 334 с.

5. Блинова МИ, Калмыкова НВ, Юдинцева НМ, Кухарева ЛВ, Пинаев ГП, Лапин АЮ, и др. Использование культивируемых клеток кожи человека для лечения трофических язв. Клеточные Культуры: информ бюл. 2006;(21):33-44.

6. Зорин ВЛ, Черкасов ВР, Зорина АМ, Деев РВ. Характеристика мирового рынка клеточных технологий. Клеточная Трансплантология и Тканевая Инженерия. 2010;5(3):96-15.

7. Пинаев ГП, Богданова МС, Кольцова АМ, ред. Клеточные технологии для регенеративной медицины. С-Петербург, РФ: Изд-во Политехн ун-та; 2011. 332 c.

8. Баранов ЕВ, Третьяк СИ, Василевич ИБ, Лобанок ЕС, Волотовский ИД. Клинические возможности применения аутогенных мультипотентных мезенхимных стромальных клеток жировой ткани при лечении пациентов с трофическими язвами нижних конечностей. Клеточная Трансплантология и Тканевая Инженерия. 2013;8(2):79-84.

9. Седов ВМ, Андреев ДЮ, Смирнова ТД, Парамонов БА, Енькина ТН, Соминина АА, и др. Клеточная терапия в лечении трофических язв нижних конечностей. Вестн Хирургии им ИИ Грекова. 2006;165(2):90-94.

10. Шаблин ДВ, Павленко СГ, Евглевский АА, Бондаренко ПП, Хуранов АА. Современные раневые покрытия в местном лечении ран различного генеза. Фундам Исследования. 2013;(12-2):361-65.

11. Chunmeng S, Tianmin C, Yongping S, Xinze R, Yue M, Jifu Q, et al. Effects of dermal multipotent cell transplantation on skin wound healing. J Surg Res. 2004 Sep;121(1):13-19.

12. ШведЮА, КухареваЛВ, Зорин ИМ, Блинова МИ, Билибин АЮ, Пинаев ГП. Взаимодействие культивируемых клеток кожи с разными структурными формами коллагена, нанесенного на полилактидную матрицу. Цитология. 2007;49(1):32-39.

13. Badiavas EV, Abedi M, Butmarc J, Falanga V, Quesenberry P. Participation of bone marrow derived cells in cutaneous wound healing. J Cell Physiol. 2003 Aug;196(2):245-50.
14. Tabata Y. Biomaterial technology for tissue engineering applications. J R Soc Interface. 2009 Jun 6;6(Suppl 3):S311-S24. doi: 10.1098/rsif.2008.0448. focus.

15. Штильман МИ. Полимеры медико-биологического назначения. Москва, РФ: Академкнига; 2006. $400 \mathrm{c}$

\section{REFERENCES}

1. Uchkin IG, Bagdasarian AG. Sovremennye podkhody klecheniiu venoznykh troficheskikh iazv [Current approaches to the treatment of venous trophic ulcers]. RMZh. Khirurgiia. 2005;21(15):810-14.

2. Abaev IuK. Rasstroistvo zazhivleniia ran i metody ikh korrektsii [Disorder of wound healing and methods of their correction]. Vestn khirurgii im II Grekova. 2005;164(1):111-13.

3. Ehrlich HP. Understanding experimental biology of skin equivalent: from laboratory to clinical use in patients with burns and chronic wounds. Am J Surg. 2004 May; 187(5A):29S-33S.

4. Babaeva AG. Regeneratsiia - fakty i perspektivy [Regeneration - facts and perspectives]. Moscow, RF: RAMN; 2009. 334 p.

5. Blinova MI, Kalmykova NV, Iudintseva NM, Kukhareva LV, Pinaev GP, Lapin AIu, i dr. Ispol'zovanie kul'tiviruemykh kletok kozhi cheloveka dlia lecheniia troficheskikh iazv [The use of cultured human skin cells for the treatment of trophic ulcers]. Kletochnye Kul'tury: inform biul. 2006;(21):33-44.

6. Zorin VL, Cherkasov VR, Zorina AM, Deev RV. Kharakteristika mirovogo rynka kletochnykh tekhnologii [Characteristics of the world market of cellular technologies]. Kletochnaia Transplantologiia i Tkanevaia Inzheneriia. 2010;5(3):96-15.

7. Pinaev GP, Bogdanova MS, Kol'tsova AM, red. Kletochnye tekhnologii dlia regenerativnoi meditsiny [Cellular technologies for regenerative medicine]. SPetersburg, RF: Izd-vo Politekhn un-ta; 2011. 332 p. 8. Baranov EV, Tret'iak SI, Vasilevich IB, Lobanok ES, Volotovskii ID. Klinicheskie vozmozhnosti primeneniia autogennykh mul'tipotentnykh mezenkhimnykh stromal'nykh kletok zhirovoi tkani pri lechenii patsientov $\mathrm{s}$ troficheskimi iazvami nizhnikh konechnostei [Clinical possibilities of using autogenic multipotent mesenchymal stromal cells of adipose tissue in the treatment of patients with trophic ulcers of lower extremities]. Kletochnaia Transplantologiia $i$ Tkanevaia Inzheneriia. 2013;8(2):79-84.

9. Sedov VM, Andreev DIu, Smirnova TD, Paramonov BA, En'kina TN, Sominina AA, i dr. Kletochnaia terapiia $\mathrm{v}$ lechenii troficheskikh iazv nizhnikh konechnostei [Cell therapy in the treatment of trophic ulcers of the lower extremities]. Vestn Khirurgii im II Grekova. 2006;165(2):90-94.

10. Shablin DV, Pavlenko SG, Evglevskii AA, Bondarenko PP, Khuranov AA. Sovremennye ranevye pokrytiia $\mathrm{v}$ mestnom lechenii ran razlichnogo geneza

[Modern wound covers in the local treatment of wounds of various origins ]. Fundam Issledovaniia. 2013;(122):361-65.

11. Chunmeng S, Tianmin C, Yongping S, Xinze R, Yue M, Jifu Q, et al. Effects of dermal multipotent cell transplantation on skin wound healing. J Surg Res. 2004 Sep;121(1):13-19.

12. Shved IuA, Kukhareva LV, Zorin IM, Blinova MI, Bilibin AIu, Pinaev GP. Vzaimodeistvie 
kul'tiviruemykh kletok kozhi s raznymi strukturnymi formami kollagena, nanesennogo na polilaktidnuiu matritsu [Interaction of cultured skin cells with different structural forms of collagen deposited on a polylactide matrix]. Tsitologiia. 2007;49(1):32-39.

13. Badiavas EV, Abedi M, Butmarc J, Falanga V, Quesenberry P. Participation of bone marrow derived cells in cutaneous wound healing. J Cell Physiol. 2003

\section{Адрес для корреспонденции}

220116, Республика Беларусь,

г. Минск, пр. Дзержинского, д. 83,

УО «Белорусский государственный

медицинский университет»,

2-я кафедра хирургических болезней, тел. +375 29 623-99-83?

e-mail: doc.e.baranov@mail.ru,

Баранов Евгений Валерьевич

\section{Сведения об авторах}

Баранов Е.В., к.м.н., доцент 2-й кафедры хирургических болезней УО «Белорусский государственный медицинский университет».

Буравский А.В., к.м.н., ассистент 2-й кафедры хирургических болезней УО «Белорусский государственный медицинский университет».

Квачева 3.Б., к.б.н., ведущий научный сотрудник лаборатории молекулярной биологии клетки ГНУ «Институт биофизики и клеточной инженерии НАН Беларуси».

Бутенко А.В., младший научный сотрудник лаборатории молекулярной биологии клетки ГНУ «Институт биофизики и клеточной инженерии НАН Беларуси».

Третьяк Д.С., к.м.н., майор медицинской службы, старший ординатор медицинского отряда ГУ «432 Главный военный клинический медицинский центр Вооруженных Сил Республики Беларусь».

Юркштович Н.К., к.Х.Н., ведущий научный сотрудник НИИ физико-химических проблем БГУ.

Цедик Л.В., научный сотрудник ГНУ «Институт порошковой металлургии».

Третьяк С.И., член-корреспондент НАН Беларуси, д.м.н., профессор, заведующий 2-й кафедрой хирургических болезней УО «Белорусский государственный медицинский университет».

Волотовский И.Д., д.б.н., академик НАН Беларуси, заведующий лабораторией молекулярной биологии клетки ГНУ «Институт биофизики и клеточной инженерии НАН Беларуси».

\section{Информация о статье}

Поступила 8 декабря 2016 г.

Принята в печать 6 февраля 2017 г. Доступна на сайте 4 мая 2017 г.
Aug; 196(2):245-50.

14. Tabata Y. Biomaterial technology for tissue engineering applications. $J R$ Soc Interface. 2009 Jun 6;6(Suppl 3):S311-S24. doi: 10.1098/rsif.2008.0448. focus.

15. Shtil'man MI. Polimery mediko-biologicheskogo naznacheniia [Polymers of biomedical application]. Moscow, RF: Akademkniga; 2006. 400 p.

\section{Address for correspondence}

220116, Republic of Belarus, Minsk, 83, Dzerzhinskiyi Ave., Belarusian

State Medical University,

Department N2 of Surgical Diseases,

Tel.: 37529 623-99-83

E-mail: doc.e.baranov@mail.ru,

Evgeniy V. Baranov

\section{Information about the authors}

Baranov E.V. PhD, Ass. Professor of department of surgical diseases N2, EE "Belarusian State Medical University".

Buravsky A.V. PhD, Ass. Professor of department N2 of surgical diseases, EE "Belarusian State Medical University".

Kvacheva Z.B. PhD (Biology), leading researcher of Laboratory of Cellular and Molecular Biology, SRE

"Institute of Biophysics and Cell Engineering of NAS of Belarus".

Butenko A.V. Junior researcher of the Laboratory of Cellular and Molecular Biology, SRE "Institute of Biophysics and Cell Engineering of NAS of Belarus".

Tretyak D.S. PhD, Major of medical service, senior resident of medical troop, SE "Main Clinical Military Medical Centre 432 of the Armed Forces of the Republic of Belarus".

Yurkshtovich N.K. PhD (chemical sciences), leading researcher of the Research Institute for Physical Chemical Problems of the Belarusian State University. Cedik L.V. Researcher of SNE "Powder Metallurgy Institute".

Tretyak S.I. Corresponding Member of NAS of Belarus, MD, Professor, Head of department of surgical diseases N2, EE "Belarusian State Medical University".

Volotovsky I.D. BD (Biology), Academician of NAS of Belarus, Head of the Laboratory of Cellular and Molecular Biology, SRE "Institute of Biophysics and Cell Engineering, NAS of Belarus".

\section{Article history}

Recieved 8 December 2016

Accepted 6 February 2017

Available online 4 May 2017 